I16hwXWE-ej4A3V9lLbNxgLQAk10hcMg5aUJTqujDoCryfXP4 (accessed 11 November 2020).

4. The Only State Electronic Database on Education (2018-2020). Derzhavne pidpryiemstvo «Inforesurs» [State Enterprise «Inforesource»]. Retrieved from: https://registry.edbo.gov.ua/ (accessed 09 November 2020).

\title{
INFLUENCE OF THE COVID-19 PANDEMIC ON THE ECONOMIC RELATIONS OF UKRAINE WITH LATVIA, LITHUANIA AND ESTONIA
}

\author{
Maryna Kachanovska ${ }^{1}$ \\ Sergey Yakubovskiy ${ }^{2}$
}

DOI: https://doi.org/10.30525/978-9934-26-002-5-26

The Baltic States are of geopolitical interest to Ukraine in the development of Baltic-Black Sea cooperation and in the pursuit of their own political and economic goals. Ukraine is constantly improving its foreign economic relations with Latvia, Lithuania and Estonia. Latvian-Ukrainian economic cooperation has good potential for development. Today, there are all prerequisites for the further development of bilateral economic cooperation, especially given Ukraine's progress towards EU integration.

The global Covid-19 pandemic has significantly affected trade relations between Ukraine and these countries, so it is important to assess the negative effect of the pandemic on the balance of goods and services, as well as the dynamics and volume of foreign direct investment between selected countries.

Table 1 presents data on trade relations between Ukraine and the Baltic States for January-September 2019-2020. It should be noted that in 2020, due to the pandemic, the volume of Ukrainian exports decreased compared to the same period in 2019. Ukrainian exports to Latvia and Estonia decreased by almost 30\%, but to Estonia by less than 1\% Imports also suffered from the current situation, however, if imports from Latvia and Lithuania to Ukraine decreased by $10.7 \%$ and $26.9 \%$ respectively, Estonia, on the contrary, exported goods to Ukraine in 2020 by 34\% more than in 2019.

Ukraine shows a positive trade balance with Latvia, as Ukrainian exports exceed Latvian imports to Ukraine. Ukraine's trade relations with Lithuania have always recorded a negative balance. The Ukrainian balance of goods

\footnotetext{
${ }^{1}$ Odesa I. I. Mechnikov National University, Ukraine

${ }^{2}$ Odesa I. I. Mechnikov National University, Ukraine
} 
with Estonia was also positive in 2019, but in 2020 it became negative and amounted to -59 million dollars. USA.

Table 1

Balance of goods of Ukraine with Lithuania, Latvia and Estonia (mln USD)

\begin{tabular}{|l|c|c|}
\hline & Jan. - Sept. 2019 & Jan. - Sept. 2020 \\
\hline Exports from Ukraine to Latvia & 228.9 & 167.3 \\
\hline Imports from Latvia to Ukraine & 118.5 & 105.8 \\
\hline $\begin{array}{l}\text { Balance of goods of Ukraine } \\
\text { with Latvia }\end{array}$ & $\mathbf{1 1 0 . 4}$ & $\mathbf{6 1 . 5}$ \\
\hline Exports from Ukraine to Lithuania & 309.9 & 307.4 \\
\hline Import from Lithuania to Ukraine & 846.0 & 618.4 \\
\hline $\begin{array}{l}\text { Balance of goods of Ukraine } \\
\text { with Lithuania }\end{array}$ & $\mathbf{- 5 3 6 . 1}$ & $\mathbf{- 3 1 1 . 0}$ \\
\hline Exports from Ukraine to Estonia & 105.6 & 77.2 \\
\hline Import from Estonia to Ukraine & 101.8 & 136.2 \\
\hline $\begin{array}{l}\text { Balance of goods of Ukraine } \\
\text { with Estonia }\end{array}$ & $\mathbf{3 . 8}$ & $\mathbf{- 5 9 . 0}$ \\
\hline
\end{tabular}

Source: calculated by author based on [1]

Due to Covid-19, Latvia lost its export position not only in relation to Ukraine, but also to other European countries. But so far, Latvian exports have stabilized somewhat because of EU support. The main items of Ukrainian exports of goods to Latvia are: mineral fuel, oil and its products; nuclear reactors, machine boilers, various chemicals and paper and cardboard. In turn, the main items of imports from Latvia to Ukraine: goods purchased in ports, pharmaceuticals, alcoholic and soft drinks and electric machines. The reasons for such a decline in exports are, first of all, the decline in world demand, including from Ukraine. In general, Latvia has suffered from Covid19 to a much lesser extent than Ukraine, so it will be able to recover its economy faster and establish foreign economic relations with other countries, including Ukraine.

The pandemic has had the greatest impact on Ukraine's bilateral trade with Lithuania, as Ukraine depends much more on Lithuanian imports than on imports from Latvia or Estonia. The main goods that Ukraine exports to Lithuania are: cereals, wood and wood products, ferrous metals and nuclear 
reactors, boilers and machinery. During the same period, Lithuania exported to Ukraine mineral fuels, oil and its products, pharmaceuticals and nuclear boilers and machinery.

Although Estonia increased its exports to Ukraine during this period, it did not significantly affect its export position in general, as its largest trading partners are Finland, Germany and Lithuania. Estonia exports nuclear reactors, boilers and equipment, fish and crustaceans, cotton wool and tanning extracts to Ukraine. The main items of Ukrainian imports to Estonia are: mineral fuels, oil and products of its distillation, ferrous metals, electric machines.

Bilateral trade in services between Ukraine and Latvia and Lithuania has also fallen by about $20 \%$, primarily due to the introduction of restrictions on the movement of people, which has led to a drop in exports of travel-related services in all countries. Ukraine generally exports financial and telecommunications services to selected countries and imports tourism services. Although their share is not very large in the total exports of these countries, but still the decline in demand for tourism from Ukraine has left its negative impact.

Latvian investments in Ukraine are focused on finance and insurance, as well as retail outlets and real estate. Ukrainian investments in Latvia exceed Latvian ones in Ukraine. The reasons may be not only the relative size of the two economies, but also market conditions. In addition, Ukraine's investment cooperation with Lithuania, Latvia and Estonia suffers from stumbling blocks, as the main factor that negatively affects this cooperation is corruption. According to the Corruption Perceptions Index for 2018, Ukraine ranks 130th out of 180 countries.

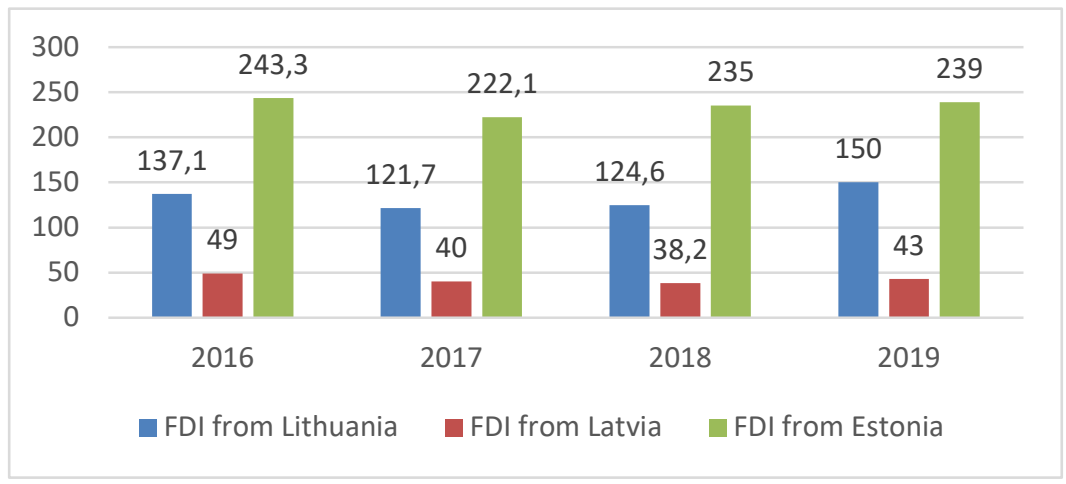

Figure 1. Dynamics of foreign direct investment from Latvia, Lithuania, Estonia to Ukraine (million USD) [1] 
The chart shows that Estonia invests the most in Ukraine, its FDI exceeds Latvia's FDI by almost 8 times. It should also be noted that in 2017, investments from all countries in Ukraine decreased slightly. The number of Lithuanian investors has not increased in recent years. Unfortunately, for these countries of the Baltic region, Ukraine is not a priority for investment.

Thus, the global Covid-19 pandemic has really had a significant impact on the development of economic relations between Ukraine and Latvia, Lithuania and Estonia. Most of these negative effects were manifested in a decrease in exports and imports in these countries. However, because of the fact that Ukraine is not a priority trading partner for these Baltic countries, they have not suffered much from the decline in Ukrainian imports. Moreover, due to the fact that Ukraine does not inspire confidence in investors of the studied countries and attracts small amounts of foreign direct investment, the pandemic will not greatly affect their further dynamics.

\author{
References: \\ 1. Derzhavna sluzhba statystyky Ukrainy. Available at: \\ http://www.ukrstat.gov.ua/operativ/menu/menu_u/zed.htm
}

\title{
COMPETITIVE ADVANTAGES OF ORGANIC PRODUCTS: THE ESSENCE AND SOURCES OF THEIR FORMATION
}

\section{Marina Kotsenko ${ }^{1}$}

DOI: https://doi.org/10.30525/978-9934-26-002-5-27

The production development and increasing the competitiveness of enterprises in the world market is an important stage in the formation of the Ukrainian economy. One of the main methods of ensuring the competitiveness of the enterprise is to identify, ensure, maintain and increase competitive advantage. Organic production is no exception. More and more agricultural producers are studying the introduction and development of organic products. Considering the trends of foreign agronomists and producers, organic production is becoming not only a way to earn and develop business, but also a conscious choice in favor of ensuring the growth of a healthy nation.

Organic products become an important indicator not only in Ukrainian economy, but also in increasing the socio-economic status of the state on the

${ }^{1}$ Polissya National University, Ukraine 